\title{
Pengaruh Pemberian Fermentasi Air Leri Dan Pupuk NPK Phonska Terhadap Pertumbuhan Tanaman Bunga Kupu-Kupu (Oxalis Triangularis)
}

\author{
Hasanuddin Kandatong ${ }^{1}$, Safruddin ${ }^{2}$ \\ Program Studi Agroteknologi Universitas Al Asyariah Mandar \\ ${ }^{1}$ hasan_kandatong@yahoo.com \\ ${ }^{2}$ Safruddin90@yahoo.com
}

\begin{abstract}
Abstrak
Penelitian ini dilaksanakan di Lingkungan Kampung Tangnga, Kelurahan Matakali, Kecamatan Matakali Kabupaten Polewali Mandar Propinsi Sulawesi Barat yang berlangsung pada bulan Desember 2014 sampai Maret 2015 yang bertujuan untuk mengetahui bagaimana respon pertumbuhan Bunga Kupu-Kupu dengan melakukan Pemberian Fermentasi Air Leri dan Pupuk NPK Phonska. Penelitian dilaksanakan dalam bentuk Rancangan Acak Kelompok yang di susun dalam bentuk Faktorial terdiri dari dua faktor yaitu Faktor pertama pemberian Fermentasi Air Leri dengan tiga taraf yaitu: A0 = Kontrol, A1= penyiraman $15 \mathrm{ml} /$ polybag, A2= penyiraman $20 \mathrm{ml} /$ Polybag, Dengan aplikasi penyiraman 2 kali seminggu,kecuali telah terjadi hujan maka Penyiraman air leri tidak dilakukan, Faktor kedua pemberian pupuk NPK Phonska dengan dua taraf yaitu : N1=6 gram/polybag, $\mathrm{N} 2=9$ gram/polybag,pemupukan dilakukan pada hari ke 21 setelah tanaman tumbuh. Hasil penelitian menunjukkan bahwa pengaruh pemberian fermentasi Air Leri $20 \mathrm{ml} /$ tanaman (A2) memberikan pengaruh lebih baik dan berbeda nyata dibanding dengan tanpa pemberian fermentasi Air Leri /tanaman (A0) dan pemberian fermentasi Air Leri $15 \mathrm{ml}$ /tanaman (A1) pada waktu kecepatan tumbuh tanaman, demikian pula dengan pemberian pupuk NPK Phonska dengan takaran 9 gram (N2) memberikan pengaruh lebih baik dan berbeda nyata dibanding dengan pemberian pupuk NPK Phonska dengan takaran 6 gram (N1) terhadap tinggi tanaman dan jumlah daun.
\end{abstract}

Kata Kunci : Fermentasi, Air Leri, Ponska, Bunga Kuри Kири

\section{PENDAHULUAN}

Saat ini bunga kupu-kupu sudah cukup dikenal di masyarakat karena banyak terlihat dan ditanam di pinggir jalan, pekarangan-pekarangan rumah, Sebagai tanaman hias yang dimasukkan ke dalam pot hias. Kadang-kadang tanaman ini tumbuh secara liar di antara semak-semak belukar, tanaman ini dengan mudah dikembangbiakan dengan media pot, asalkan memenuhi beberapa persyaratan tumbuh bagi tanaman ini (Agustina, 2011).

Mentimun adalah salah satu sayuran buah yang banyak di konsumsi segar oleh masyarakat Indonesia. Meskipun bukan tanaman Indonesia, tetapi mentimun sudah sangat di kenal oleh masyarakat Indonesia. Jenis sayuran ini dengan mudah ditemukan hampir seluruh pelosok Indonesia. Mentimun juga dikenal dalam dunia kesehatan sebagai obat batuk, penurunan panas dalam, bahkan mentimun yang dikukus dan di simpan sehari semalam lalu di diamkan langsung akan berkhasiat mengurangi sakit tenggorokan dan batuk-batuk.

Dalam proses pengembangan tanaman mentimun sering mengalami kendala, terutama dalam hal sifat fisik dan kimia tanah. Tanah yang kurang subur menyebabkan produksi menurun. Untuk itu dalam penanaman mutlak diperlukan pengolahan tanah dan penambahan unsur hara. Dalam hal ini dapat dilakukan pemanfaatan pupuk kandang dan pemupupukan anorganik sebagai solusi yang dapat dilakukan (Fajar yuyanto 2013).

Produksi tentang mentimun di Indonesia sesuai data BPS (2008) masih rendah yaitu 3,5 ton/ha sampai 4,8 ton/ha, padahal produksi mentimun hibrida bisa mencapai 20 ton/ha. Budidaya tanaman mentimun dalam skala produksi yang tinggi dan intensif belum banyak dilakukan, pada umumnya tanaman mentimun ditanam sebagai tanaman selingan (Arlina 2015).

\section{BAHAN DAN METODE}

Penelitian ini dilaksanakan pada bulan Agustus sampai bulan November Tahun 2016 di Desa Mekkatta Kecamatan Malunda Kabupaten Majene Provinsi sulawesi Barat. Penelitian menggunakan Rancangan Acak Kelompok ( RAK ) 
dengan pola faktorial. yang terdiri dari 2 ( dua ) faktor yaitu : Faktor pertama yaitu Pupuk Kandang Yang $\operatorname{Berbeda}(\mathrm{K})$ terdiri dari 3 taraf yaitu K1: pupuk kandang ayam K2: pupuk kandang kambing K3 pupuk kandang sapi masing masing $200 \mathrm{~g} /$ tanaman

Faktor kedua adalah Media Tanam ( T ) dengan 3 taraf perlakuan yaitu T1: Media Tanam Menggunakan arang sekam + Tanah, T2 :Media Tanam Menggunakan serbuk gergaji + Tanah dan T3: Media tanam menggunakan pasir + Tanah

Setiap perlakuan diulang sebanyak 3 kali, sehingga terdapat 27 unit penelitian setiap unit penelitian menggunakan 2 tanaman, sehingga jumlah tanaman seluruhnya 54 tanaman.

\section{HASIL DAN PEMBAHASAN \\ Waktu Muncul Tunas ( hari )}

Sidik ragam menunjukkan bahwa pemberian pupuk kandang berbeda ( $\mathrm{K}$ ) dan

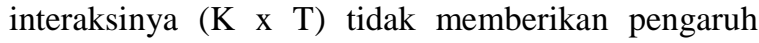
nyata. Sedangkan media tanam berbeda ( $\mathrm{T}$ ) memberikan pengaruh sangat nyata terhadap waktu muncul tunas.

Tabel 1. Rata-Rata Waktu Muncul Tunas (Hari) Pada Pemberian Berbagai Pupuk Kandang Yang Berbeda Dengan Penggunaan Media Tanam Yang Berbeda Terhadap Pertumbuhan Dan Produksi Tanaman Mentimun.

\begin{tabular}{ccccc}
\hline $\begin{array}{c}\text { Pupuk } \\
\text { Kandang } \\
\text { Berbeda }\end{array}$ & \multicolumn{3}{c}{ Media Tanam Berbeda } & Rata-Rata \\
\cline { 2 - 4 } & $\mathrm{T} 1$ & $\mathrm{~T} 2$ & $\mathrm{~T} 3$ & \\
\hline $\mathrm{K} 1$ & 3,67 & 3,00 & 3,00 & 3,22 \\
$\mathrm{~K} 2$ & 3,33 & 3,00 & 3,00 & 3,11 \\
$\mathrm{~K} 3$ & 3,67 & 3,33 & 3,00 & 3,33 \\
\hline Rata-rata & $3,55^{\mathrm{bc}}$ & $3,11^{\mathrm{a}}$ & $3,00^{\mathrm{a}}$ & \\
\hline $\begin{array}{c}\text { NP.UJBD } \\
\text { Taraf } \alpha \\
0,05\end{array}$ & 0,38 & 0,37 & & \\
& & & &
\end{tabular}

Keterangan : angka yang diikuti oleh huruf yang tidak sama berarti berbeda nyata pada uji jarak berganda duncan taraf $\alpha 0,05$

Hasil analisis statistik Uji Jarak berganda duncan taraf $\alpha 0,05$ pada tabel 1 menunjukkan bahwa penggunaan media tanam menggunakan Pasir ( T3 ) memberikan pengaruh lebih baik dan berbeda sangat nyata dibandingkan dengan media tanam menggunakan Arang Sekam ( T1 ) dan Media tanam menggunakan Serbuk Gergaji ( T2). Hal ini diduga karena kandungan unsur hara makro yang terkandung dalam media tanam pasir yang mampu mempercepat waktu munculnya tuas, hal ini sesuai yang dikutib dalam blok (Tanaman advertisemen 2015) Bahwa Media tanam bertekstur pasir sangat mudah diolah, tanah jenis ini memiliki aerasi (ketersediaan rongga udara) dan drainase yang baik. Pasir mengandung unsur hara phospor $(0,08 \mathrm{~g})$, kalsium (2,53 g), $\mathrm{Fe}_{2} \mathrm{O}_{3}(5,19 \mathrm{~g})$ dan $\mathrm{MgO}$ (1,02 g) (Anonim, 2015).

\section{Tinggi tanaman ( $\mathrm{cm}$ )}

Sidik ragam menunjukkan bahwa pemberian pupuk kandang berbeda ( $K$ ) dan interaksinya $(\mathrm{K} \times \mathrm{T})$ tidak memberikan pengaruh nyata. Sedangkan media tanam berbeda ( $\mathrm{T}$ ) memberikan pengaruh sangat nyata terhadap Tinggi Tanaman.

Tabel 2. Rata-Rata Tinggi Tanaman (Cm) Pada Pemberian Berbagai Pupuk Kandang Yang Berbeda Dengan Penggunaan Media Tanam Yang Berbeda Terhadap Pertumbuhan Dan Produksi Tanaman Mentimun.

\begin{tabular}{ccccc}
\hline $\begin{array}{c}\text { Pupuk } \\
\text { Kandang } \\
\text { Berbeda }\end{array}$ & \multicolumn{3}{c}{ Media Tanam Berbeda } & $\begin{array}{c}\text { Rata- } \\
\text { Rata }\end{array}$ \\
\cline { 2 - 4 } & $\mathrm{T} 1$ & $\mathrm{~T} 2$ & $\mathrm{~T} 3$ & \\
\hline K1 & 130,93 & 147,83 & 148,13 & 142,29 \\
K2 & 129,52 & 146,62 & 16,07 & 140,73 \\
K3 & 131,68 & 147,65 & 146,93 & 142,08 \\
\hline Rata-rata & $130,71^{\mathrm{a}}$ & $147,36^{\mathrm{b}}$ & $147,03^{\mathrm{a}}$ & \\
\hline $\begin{array}{c}\text { NP.UJBD } \\
\text { Taraf } \alpha \\
\text { 0,01 }\end{array}$ & 3,26 & 3,42 & & \\
\hline
\end{tabular}

Keterangan : angka yang diikuti oleh huruf yang tidak sama berarti berbeda nyata pada uji jarak berganda duncan taraf $\alpha 0,1$.

Hasil analisis statistik Uji Jarak berganda duncan taraf $\alpha 0,01$ pada tabel 2 menunjukkan bahwa penggunaan media tanam menggunakan Serbuk Gergaji ( T2 ) memberikan pengaruh lebih baik dan berbeda sangat nyata dibandingkan dengan Media tanam menggunakan arang sekam ( T1 ) dan menggunakan Pasir (T3). Hal ini diduga karena kandungan unsur hara Nitrogen 0,04-0,10\% yang terkandung dalam media tanam serbuk gergaji yang mampu meningkatkan pertumbuhan tanaman, Nitrogen Berfungsi sebagai Pembentukan atau 
pertumbuhan bagian vegetatif tanaman, seperti daun, batang, dan akar. Kemudian berperang penting dalam hal pembentukan hijau daun yang berguna sekali dalam proses fotosinesis dan membentuk protein, lemak, dan berbagai persenyawaan organik (Anonom 2015).

\section{Umur Berbunga ( hari )}

Sidik ragam menunjukkan bahwa pemberian pupuk kandang berbeda ( $\mathrm{K}$ ) dan interaksinya ( $\mathrm{K}$ x T) tidak memberikan pengaruh nyata. Sedangkan media tanam berbeda ( $\mathrm{T}$ ) memberikan pengaruh sangat nyata terhadap Umur Berbunga.

Tabel 3.Rata-Rata Umur Berbunga (Hari) Pada Pemberian Berbagai Pupuk Kandang Yang

Berbeda Dengan Penggunaan Media Tanam Yang Berbeda

\begin{tabular}{|c|c|c|c|c|}
\hline \multirow{2}{*}{$\begin{array}{c}\text { Pupuk } \\
\text { Kandang } \\
\text { Berbeda }\end{array}$} & \multicolumn{3}{|c|}{ Media Tanam Berbeda } & \multirow{2}{*}{$\begin{array}{l}\text { Rata- } \\
\text { Rata }\end{array}$} \\
\hline & $\mathrm{T} 1$ & $\mathrm{~T} 2$ & T3 & \\
\hline K1 & 26,33 & 25,67 & 25,33 & 25,77 \\
\hline $\mathrm{K} 2$ & 26,67 & 25,67 & 25,00 & 25,78 \\
\hline K3 & 26,67 & 26,33 & 25,00 & 26,00 \\
\hline Rata-rata & $26,56^{\mathrm{bc}}$ & $25,89^{\mathrm{ab}}$ & $25,11^{\mathrm{a}}$ & \\
\hline \multicolumn{5}{|l|}{ NP.UJBD } \\
\hline $\begin{array}{c}\text { Taraf } \alpha \\
0,01\end{array}$ & 0,61 & 0,65 & & \\
\hline
\end{tabular}

Keterangan : angka yang diikuti oleh huruf yang tidak sama berarti berbeda nyata pada uji jarak berganda duncan taraf $\alpha 0,01$

Hasil analisis statistik Uji Jarak berganda duncan taraf $\alpha 0,05$ pada tabel 3 menunjukkan bahwa penggunaan media tanam Menggunakan menggunakan Pasir ( T3 ) memberikan pengaruh lebih baik dan berbeda sangat nyata dibandingkan dengan Media tanam menggunakan serbuk gergaji ( T2 ) dan Media tanam menggunakan arang sekam ( T1). hal ini diduga karena kandungan unsur hara fhosfor ( $0,08 \mathrm{~g}$ ) yang terkandung dalam media tanam pasir mampu mempercepat proses pembungaan pada tanaman mentimun (Anonim 2015).

\section{Jumlah Buah ( buah )}

Hasil pengamatan Jumlah Buah ( buah ) dan sidik ragam disajikan pada Tabel lampiran 4a dan 4b. Sidik ragam menunjukkan bahwa pemberian pupuk kandang berbeda ( $\mathrm{K}$ ) dan interaksinya ( $\mathrm{K}$ x T) tidak memberikan pengaruh nyata. Sedangkan media tanam berbeda ( $\mathrm{T}$ ) memberikan pengaruh sangat nyata terhadap Jumlah Buah.
Tabel 4. Rata-Rata Jumlah Buah (buah) pada pemberian berbagai pupuk kandang yang berbeda dengan penggunaan media tanam yang berbeda

\begin{tabular}{ccccc}
\hline $\begin{array}{c}\text { Pupuk } \\
\text { Kandang } \\
\text { Berbeda }\end{array}$ & \multicolumn{3}{c}{ Media Tanam Berbeda } & $\begin{array}{c}\text { Rata- } \\
\text { Rata }\end{array}$ \\
\cline { 2 - 4 } K1 & $6,67^{\mathrm{a}}$ & $7,67^{\mathrm{a}}$ & $9,00^{\mathrm{bc}}$ & 7,78 \\
$\mathrm{~K} 2$ & $6,67^{\mathrm{a}}$ & $8,00^{\mathrm{b}}$ & $8,00^{\mathrm{b}}$ & 8,55 \\
$\mathrm{~K} 3$ & $6,33^{\mathrm{a}}$ & $7,67^{\mathrm{b}}$ & $7,33^{\mathrm{a}}$ & 7,11 \\
\hline Rata-rata & 7,55 & 7,78 & 8,11 & \\
\hline $\begin{array}{c}\text { NP.UJBD } \\
\text { Taraf } \alpha \\
0,01\end{array}$ & 0,86 & 0,91 & & \\
\hline
\end{tabular}

Keterangan : Angka yang diikuti oleh huruf yang tidak sama berarti berbeda nyata pada Uji Jarak berganda duncan taraf $\alpha 0,01$

Hasil analisis statistik Uji Jarak berganda duncan taraf $\alpha 0,01$ pada tabel 4 menunjukkan bahwa penggunaan media tanam Menggunakan Pasir ( T3 ) memberikan pengaruh lebih baik dan berbeda sangat nyata dibandingkan dengan Media tanam menggunakan serbuk gergaji ( T2 ) dan Media tanam menggunakan arang sekam ( T1) terhadap jumlah Buah.

Hal ini diduga karena kandungan fospor $(\mathrm{P})$ yang dimili oleh media tanam Menggunakan pasir yang mampu memacu pembentukan bunga dan buah, bahanpembentuk inti sel dan dinding sel, mendorong pertumbuhan akar muda dan pemasakan biji, pembentukan klorofil pentimg dalam cadangan transfer energy.

Berat Buah ( gram )

Sidik ragam menunjukkan bahwa pemberian pupuk kandang berbeda ( $\mathrm{K}$ ) dan interaksinya ( $\mathrm{K}$ x T) tidak memberikan pengaruh nyata. Sedangkan media tanam berbeda ( $\mathrm{T}$ ) memberikan pengaruh sangat nyata terhadap Berat Buah.

Tabel 5. Rata-Rata Berat Buah (gram) pada pemberian berbagai pupuk kandang yang berbeda dengan penggunaan media tanam yang berbeda

\begin{tabular}{|c|c|c|c|c|}
\hline \multirow{2}{*}{$\begin{array}{c}\text { Pupuk } \\
\text { Kandang } \\
\text { Berbeda }\end{array}$} & \multicolumn{3}{|c|}{ Media Tanam Berbeda } & \multirow{2}{*}{$\begin{array}{l}\text { Rata- } \\
\text { Rata }\end{array}$} \\
\hline & $\mathrm{T} 1$ & $\mathrm{~T} 2$ & T3 & \\
\hline
\end{tabular}




\begin{tabular}{ccccc} 
K1 & 346,00 & 365,33 & 363,67 & 358,33 \\
K2 & 349,33 & 365,67 & 364,00 & 359,66 \\
K3 & 350,33 & 366,00 & 364,67 & 360,33 \\
\hline Rata-rata & $348,55^{\text {a }}$ & $365,66^{\text {b }}$ & $364,11^{\text {a }}$ & \\
\hline $\begin{array}{c}\text { NP.UJBD } \\
\text { Taraf } \alpha \\
0,01\end{array}$ & 8,17 & 8,59 & & \\
& & & &
\end{tabular}

Keterangan : angka yang diikuti oleh huruf yang tidak sama berarti berbeda nyata pada uji jarak berganda duncan taraf $\alpha 0,01$

Hasil analisis statistik Uji Jarak berganda duncan taraf $\alpha 0,01$ pada tabel 5 menunjukkan bahwa penggunaan media tanam Menggunakan serbuk gergaji ( T2 ) memberikan pengaruh lebih baik dan berbeda sangat nyata dibandingkan denagan Media tanam menggunakan pasir ( T3 ) dan Media tanam menggunakan Arang sekam ( T1 ) terhadap berat Buah.

Menurut Mang Yono (2015) bahwa pada tanaman mentimun setelah berbunga banyak melakukan pembentukan buah yang kenyataanya pada waktu-waktu tersebut diperlukan unsur-unsur atau zat-zat pembentuk yang cukup sesuai dengan kegiatan-kegiatan pertukaran zatnya yang intensif, dengan kata lain sesuai dengan kegiatan kepentingan berbagai proses fisiologisnya dimana tanaman itu memerlukan unsur hara yang cukup sehungga berdasar kegiatan kepentingannya itu perlu pemupukan (pemberian unsur hara) yang sesuai dengan keperluannya yang dapat diberikan melalui daun atau melalui tanah untuk selanjutnya di absorbsi melalui akar tanaman.

\section{Panjang Buah ( cm )}

Sidik ragam menunjukkan bahwa pemberian pupuk kandang berbeda ( $\mathrm{K}$ ) dan interaksinya ( $\mathrm{K} \mathrm{x}$ T) tidak memberikan pengaruh nyata. Sedangkan media tanam berbeda ( $\mathrm{T}$ ) memberikan pengaruh sangat nyata terhadap Panjang Buah. Rata-Rata Panjang Buah $(\mathrm{cm})$ pada pemberian berbagai pupuk kandang yang berbeda dengan penggunaan media tanam yang berbeda terhadap pertumbuhan dan produksi tanaman mentimun.

\section{KESIMPULAN}

Berdasarkan hasil penelitian yang telah dilakukan maka dapat disimpulkan bahwa :

1. Interaksi antara pemberian berbagai jenis pupuk kandang dan media tanam yang berbeda tidak memberikan pengaruh nyata terhadap parameter waktu muncul tunas, tinggi tanaman, umur berbunga, jumlah buah, panjang buah, dan berat buah.

2. Pemberian berbagai jenis pupuk kandang ( $\mathrm{K}$ ) tidak memberikan pengaruh nyata terhadap parameter waktu muncul tunas, tinggi tanaman, umur berbunga, jumlah buah, panjang buah, dan berat buah.

3. Penggunaan media tanam yang berbeda ( $\mathrm{T}$ ) memberikan hasil terbaik terhadap parameter waktu muncul tunas, tinggi tanaman, umur berbunga, jumlah buah, panjang buah, dan berat buah.

\section{DAFTAR PUSTAKA}

Alam tani,2013 pupuk kandang http: alamtani.com/pupuk kandang.html

Arlina 2015, Mengenal karakteristik dan syarat tumbuh.html w.w.w. Petani hebat.com/2015/10/klasifikasasi dan morfologi tanaman timun.html

Cecep Risnandar. Pemberian pupuk kandang. http//www.academiedu. diakses 21 juni 2016.

Fajar Yulyanyo, 2013 Karakteristik Tanaman Mentimun http//anakindonesia95.blogspot.co.id/2013/0 9/faktor-faktor-yang mempeng aruhi.html Diakss hari senin 07 februari 2017 jam 16:34

Ibu Tani 2011, Asal usul Tanaman Mentimun repository.usu.ac.id/bitstream/123456789/2 0895/2/Reference.pdf

Nangiman,2014,http://www.nangimam.com/2014/02/ manfaat-kotoran-ayam-sebagai-pupuk.html

Sumpena, U. 2001. Budidaya Mentimun Intensif dengan Mulsa Secara Tumpang Gilir. Penebar Swadaya. Jakarta. Hal, 1-46

Sutanto, 2002. Penerapan Pertanian Organik, bungamasamba.blogspot.com/2010/10/maka lah-biologi.htm

Tanaman advertisement, 2015. http//www.tipsberkebun.com// jenis-jenis media tanam. Diakses 20 juni jam 13:17

Repository.usu.ac.id/bitstream/12repository.u su.ac.id/bitstream/123456789/28859/2/Refer ence.pdf

Mang Yono, 2015. Ciri ciri Tanaman Mentimun https://www.mangyono.com/2015/07/ciriciri-tanaman-mentimun.html

Medionovianto, D. 2008. Membuat Pupuk Kompos dari Kotoran Sapi. Tabloid Sinar Tani. Jakarta. Diposkan oleh Hidayattullah di 05.37

12/Refpupukorganiklampung.blogspot.com/2 013_09_01_archive.html 
Media neliti, 2013 Manfaat penambahan arang sekam

https://media.neliti.com/media/publications/
58740-ID-pengaruh-penambahan-arang-danabu-sekam.pdf 